\title{
FRUIT SIZE AND QUALITY OF PINEAPPLES CV. VITÓRIA IN RESPONSE TO MICRONUTRIENT DOSES AND WAY OF APPLICATION AND TO SOIL COVERS ${ }^{1}$
}

\author{
AIALA VIEIRA AMORIM ${ }^{2}$, CLAUDIVAN FEITOSA DE LACERDA ${ }^{3}$, \\ CARLOS FARLEY HERBSTER MOURA ${ }^{4}$, ENÉAS GOMES FILHO 5
}

\begin{abstract}
The objective of this study was to evaluate the effects of foundation and leaf fertilization with micronutrients on fruit size and quality of pineapple cv. Vitória under the environmental conditions of the Baixo Acaraú irrigated perimeter in Northern Ceará State, Brazil, under two covers (bagana and black plastic) of the sandy soil of low fertility. The experimental design was a randomized split blocks one with four levels of soil dressing and four levels of foliar fertilization, with five replications. Micronutrient soil dressing was studied as FTE-12 at doses of $0,60,120$ and $180 \mathrm{~kg} \mathrm{ha}^{-1}$. The four levels of foliar fertilization were: LF0 (without fertilizer), LF 1 (15 leaf fertilization, using the amount of $1158.75 \mathrm{~g} \mathrm{Fe} \mathrm{ha}^{-1}, 844.65 \mathrm{~g} \mathrm{Mn}$ ha $^{-1}, 391.5 \mathrm{~g} \mathrm{ha}^{-1} \mathrm{Zn}, 322.65 \mathrm{~g} \mathrm{ha}^{-1} \mathrm{Cu}$ and $216 \mathrm{~g} \mathrm{ha}^{-1} \mathrm{~B}$ ), LF2 (15 leaf fertilization, using twice the quantities of level LF1) and LF3 (15 leaf fertilization, using three times the amount of level LF1). At 13 months after planting the micropropagated plantlets was carried out the floral induction treatment and five months later the fruit harvest determining the following variables: fruit weight and median diameter, soluble solids content (SS) and titratable acidity (TA). Both fruit weight and diameter increased with increasing doses of micronutrients applied to the soil and to the leaves, of plants grown both on bagana soil cover and plastic mulch. On the other hand fruit pulp quality was little affected by the treatments studied. There were a small increase of SS contents for plants grown on bagana soil cover and a small decrease of titratable acidity for those grown on plastic mulch, in both cases just in response to micronutrient foliar application.
\end{abstract}

Index terms: Ananas comosus comosus, fertilization, soluble solids, titratable acidity.

\section{QUALIDADE DO FRUTO DE ABACAXI 'VITORIA' SOB ADUBAÇÃO}

RESUMO - Este trabalho teve como objetivo avaliar os efeitos da adubação de fundação e foliar com micronutrientes sobre aspectos físicos e qualitativos do abacaxi cv. Vitória, nas condições do Perímetro Irrigado Baixo Acaraú, norte do Estado do Ceará, sob duas coberturas do solo (bagana e plástico preto) arenoso e de baixa fertilidade. O delineamento experimental utilizado foi em blocos casualizados, em parcelas subdivididas, com quatro doses de adubação de fundação, e quatro níveis de adubação foliar, com cinco repetições. Para a adubação de fundação foi utilizado FTE-12 nas doses de 0; 60; 120 e $180 \mathrm{~kg} \mathrm{ha}^{-1}$. Os quatro níveis de adubação foliar foram: AF0 (sem adubação); AF1 (15 adubações foliares, usando um total de 1.158,75 g ha $^{-1}$ de Fe, 844,65 $\mathrm{g} \mathrm{ha}^{-1}$ de Mn, 391,5 $\mathrm{g} \mathrm{ha}^{-1}$ de Zn, 322,65 $\mathrm{g} \mathrm{ha}^{-1}$ de Cu e $216 \mathrm{~g}^{-1} \mathrm{a}^{-1}$ de B); AF2 (15 adubações foliares, usando o dobro das quantidades do nível AF1), e AF3 (15 adubações foliares, usando o triplo das quantidades do nível AF1). Aos 13 meses após o plantio das mudas obtidas por micropropagação, foi realizado o tratamento de indução floral, e cinco meses mais tarde, a colheita, determinando-se as seguintes variáveis dos frutos: peso, diâmetro mediano, sólidos solúveis (SS) e acidez titulável (AT). O peso e o diâmetro mediano do fruto aumentaram com a elevação das doses de micronutrientes, aplicados no solo e via foliar, nas plantas cultivadas sob ambas as coberturas de solo. Por outro lado, a qualidade da polpa do fruto foi pouco afetada pelos tratamentos estudados. Foi observado pequeno aumento do teor de sólidos solúveis nos frutos das plantas cultivadas em solo, com cobertura de bagana, e pequena redução da acidez titulável no caso da cobertura com plástico preto, em ambos os casos, apenas para os micronutrientes aplicados via foliar. Termos para indexação: Ananas comosus comosus, adubação, sólidos solúveis e acidez titulável.

\footnotetext{
${ }^{1}$ Trabalho Sinfruit 164 - Simpósio Internacional de Fruticultura - Avanços na Fruticultura (17 a 21 Outubro)

${ }^{2}$ Dra. em Agronomia/Fitotecnia, Departamento de Fitotecnia-UFC, Fortaleza-CE; Av. Mister Hull, s/n, Campus do Pici, CEP: 60455-760, Fortaleza-CE. E-mail: aialaamorim@hotmail.com

${ }^{3}$ Dr. Professor do Departamento de Irrigação e Drenagem, DENA-UFC, Fortaleza-CE. E-mail: cfeitosa@ufc.br

${ }^{4}$ Pesquisador da Embrapa Agroindústria Tropical, Fortaleza-CE. E-mail: farley@cnpat.embrapa.br

${ }^{5}$ Dr. Professor do Departamento Bioquímica e Biologia Molecular, UFC, Fortaleza-CE. E-mail: egomesf@ufc.br
} 


\section{INTRODUCTION}

The nutritional status of the pineapple plants has a major influence on plant growth, and consequently, production and fruit quality (COELHO et al., 2007). To ensure good acceptance of the fruits in the consumer market, the producers try to raise the quality standards seeking to optimize their system of mineral fertilization. In general, little is known about the effects of fertilization with micronutrients on tropical crops. According to Siebeneichler et al. (2008), currently there seems to be some awareness among farmers about the use of micronutrients in the culture of pineapple, but its use is usually done empirically.

In studying the quality of pineapples, various physical and physical-chemical characteristics are evaluated, such as: fruit weight and diameter, soluble solids (SS) and titratable acidity (TA), among others. One of the requirements of the consumer market for pineapple is the fruit size. According to Coelho et al. (2007), increases in average weight of the pineapple fruit can be obtained when plants are subjected to a proper mineral fertilization.

A pineapple with better quality has a high SS content and a low TA content, and this last factor is inversely correlated to the $\mathrm{pH}$ and vitamin $\mathrm{C}$ of fruit (Ramos et al., 2010). According to the Center for Quality of Horticulture - CQH (2003), the minimum content of soluble solids in pineapple fruits, among other quality requirements, must correspond to 12 ${ }^{\circ} \mathrm{Brix}$, which is the marketing standard to be adopted. On the other hand, Chitarra and Chitarra (2005) argued that fruit of good quality for fresh consumption must have SS values between 14 to $16^{\circ} \mathrm{Brix}$.

From the agronomic point of view, one of the factors taken into account by producers, before planting, is the soil cover. In general, the soil cover is used to minimize the effects of erosion, conserve soil moisture by reducing evapotranspiration, control the use of irrigation water in the range of the crop plants and reduce the growth of weeds.

Considering that to get fruit of excellent quality, it is extremely important to have proper mineral fertilization. A goal of this study was to evaluate the effect of micronutrients applied to the soil and on the leaves on fruit size and quality of 'Vitória' pineapples produced in the Baixo Acaraú irrigated perimeter under two types of soil covers: bagana and black plastic.

\section{MATERIALS AND METHODS}

The experiment was carried out from December 2008 to October 2010 in a 0.348 ha irrigated area in Marco county, located in the northern part of the state of Ceará, about $210 \mathrm{~km}$ from the state's capital, Fortaleza. The region has a Aw' tropical climate according to the Köppen's classification, at a latitude of $3^{\circ} 07^{\prime} 13^{\prime \prime} \mathrm{S}$ and a longitude of $40^{\circ} 05^{\prime} 13^{\prime \prime} \mathrm{W}$. The soil of the experimental area presents a sandy texture, a density of $1.59 \mathrm{~g} \mathrm{~kg}^{-1}$ and the following chemical characteristics in the 0-20 cm layer: $\mathrm{pH} 5.8, \mathrm{EC} 0.15$ $\mathrm{dS} \mathrm{m}^{-1}$ and $0.77,0.30,0.08,0.02$ and 0.75 mmolc $\mathrm{kg}^{-1}$ of $\mathrm{Ca}, \mathrm{Mg}, \mathrm{K}, \mathrm{Na}$ and $\mathrm{Al}$, respectively.

The micropropagated, 90 days old plantlets of the 'Vitória' pineapple were transferred from the trays to black polyethylene plastic bags containing as substrate sand with addition of $800 \mathrm{~g}$ of superphosphate per $1 \mathrm{~m}^{3}$. Thereafter the plantlets were acclimated for six months, and during this period, irrigated twice a week with water at an electrical conductivity of $0.44 \mathrm{dS} \mathrm{m}^{-1}$ and $\mathrm{pH} 3.8$. The planting in the field was performed in April 2009. The plants were arranged in double rows, spaced $0.90 \times 0.40$ x $0.30 \mathrm{~m}$, in an area of $38.4 \mathrm{~m}$ by $88.0 \mathrm{~m}$, totaling 14,080 plants in 0.348 ha. Each plot consisted of four subplots, with four double rows with 11 plants per row. The two central lines were the useful area of the subplot.

The work was set up by two equal experiments with different soil covers, one of black polyethylene plastic and the other of carnauba bagana. In both, the plants were subjected to different doses of micronutrients applied in the foundation and as leaf fertilization.

The experimental design was a randomized split blocks one with four levels of fertilization applied at planting as foundation and four levels of foliar fertilization, with five replications. At planting was used the commercial formulation of micronutrients FTE-12, which was applied at doses of 0,60 , 120 and $180 \mathrm{~kg} \mathrm{ha}^{-1}$; the four levels of foliar fertilization were: LF0 (without fertilizer), LF 1 (15 foliar fertilizations using the amounts of $1158.75 \mathrm{~g} \mathrm{Fe} \mathrm{ha}^{-1}$, $844.65 \mathrm{~g} \mathrm{Mn} \mathrm{ha}^{-1}, 391.5 \mathrm{~g} \mathrm{ha}^{-1} \mathrm{Zn}, 322.65 \mathrm{~g} \mathrm{ha}^{-1} \mathrm{Cu}$ and $216 \mathrm{~g} \mathrm{ha}^{-1} \mathrm{~B}$ ); LF2 (15 foliar fertilizations, using twice the quantities of level LF1) and LF3 (15 foliar fertilizations, using three times the amount of level LF1). The foliar fertilization was performed monthly, and the concentrations defined by using as a base a modified Murashige and Skoog nutrient solution. The total volume of the solution in each application was $463 \mathrm{~L} \mathrm{ha}^{-1}$.

Macronutrients were applied to all plants via fertigation, from two months after planting following recommendations from local producers. The irrigation management was based on soil moisture sensors, TOPDEA type, installed at 15 and $25 \mathrm{~cm}$ 
soil depth. The first represented the soil layer from 5 to $15 \mathrm{~cm}$, while the second represented the layer of 15 to $25 \mathrm{~cm}$ (CRUZ et al., 2010).

At one month after planting was applied the fungicide Aliette for control of Phytophthora rot. At six and 12 months, mealy bugs were controlled by use of Methyl parathion 600 EC. Weed control was performed using Metrimex 500. The floral induction was done at 13 months after planting by spraying plants with ethephon at a concentration of $1500 \mathrm{mg}$ $\mathrm{L}^{-1}$, when the green mass of the largest plants sampled presented a weight of about $2 \mathrm{~kg}$.

The harvest was done during October 2010, when fruits were physiologically mature presenting fully yellow rind color. All fruits of the subplots were harvested but average weight obtained by determination of the weight of 10 fruits per subplot. One of those fruits was then sampled based on intermediate size for physical and physical-chemical evaluations. After harvesting, the pineapples were identified, packed in plastic boxes with a capacity of $20 \mathrm{~kg}$, and then transported at cool temperature of about $15^{\circ} \mathrm{C}$ until the laboratory, where they remained for 24 hours at the same temperature before doing the analytical evaluations.

For evaluation of the physical-chemical and chemical properties, the fruit was peeled and cut lengthwise without the central axis, with sharp knives. The slices were processed in a Walita centrifuge, with a 650 watt motor, and sieve microtritution with micro-holes. The resulting liquid was used for immediate measurements of SS and TA.

Measurements of the levels of SS were taken using a digital refractometer (model PR - 100, Palette, Atago Co.LTD., Japan) with automatic temperature compensation. The SS were determined according to the methodology recommended by Brasil (2005), and the results expressed in ${ }^{\circ}$ Brix. To determine the TA, a 1 $\mathrm{g}$ sample of juice was placed in a $125 \mathrm{~mL}$ Erlenmeyer flask and diluted with $50 \mathrm{~mL}$ of water under constant agitation. Then three drops of $1 \%$ phenolphthalein were added and titrate sample with a solution of 0.1 $\mathrm{N} \mathrm{NaOH}$ until the turning point or equivalence. The results were expressed as a percentage of citric acid, according to the methodology of Brasil (2005).

The data were subjected to analysis of variance by $\mathrm{F}$ test at $5 \%$ probability using the software "Assistat 7.5 BETA". Data of variables with treatment significant effects were submitted to regression analysis.

\section{RESULTS AND DISCUSSION}

Both fruit weight and diameter were af- fected by micronutrients fertilizations done to the soil under the form of FTE and to the leaves, as well as by the interaction of these two factors studied (Table 1). On the other hand, fruit pulp quality expressed by the soluble solids and titratable acidity was little affected by the treatments studied. The only significant effects occurred for SS on bagana soil cover and for TA on plastic soil cover. In both experiments, there was an increase in fruit weight and diameter in response to the application of FTE-12, even in the absence of leaf fertilization (Figure 1 and 2). Similarly, there were positive responses on fruit weight and diameter provided by foliar applications of micronutrients, even in the absence of FTE-12 (Figure 1 and 2). However, the increments provided by FTE-12 were higher than those obtained for foliar fertilization (Figure 1 and 2 ), indicating the interaction between those factors (Table 1).

At the highest level of leaf fertilization, in the experiment with bagana, for each $\mathrm{kg} \mathrm{ha}^{-1} \mathrm{FTE}$ 12 applied there was an increase of fruit weight by $0.0026 \mathrm{~kg}$, while at the lowest level of foliar fertilization this increase was $0,0021 \mathrm{~kg}$ (Figure 1). The highest fruit weights observed in this study were 1.26 and $1.31 \mathrm{~kg}$ for plants at the highest doses of FTE-12 and leaf fertilization in the experiment with bagana and black plastic, respectively (Figure 1). These results are lower than those observed by Ventura et al. (2009), who found an average weight of $1.5 \mathrm{~kg}$ for the 'Vitória' pineapple grown in the state of Espírito Santo. On the other hand, Silva et al. (2010) found a maximum weight of $1.0 \mathrm{~kg}$ for 'Vitória' pineapples grown with a dose of $409.2 \mathrm{~kg} \mathrm{~N} \mathrm{ha}^{-1}$ in the state of Paraíba. Siebeneichler et al. (2008), working with 'Pérola' pineapple subjected to different treatments with $\mathrm{B}$, found no significant changes of fruit weight observing values in the range of 1.653 to $1.696 \mathrm{~kg}$. Comparing the doses of 0 and $180 \mathrm{~kg} \mathrm{ha}^{-1}$ FTE-12, the increase in fruit diameter at the highest level of leaf fertilization was $10.92 \%$ in the experiment with bagana (Figure $2 \mathrm{~A}$ ) and $28.91 \%$ in the experiment with black plastic (Figure 2B). The highest values of this variable were 12.07 and $12.84 \mathrm{~cm}$, observed in experiments with bagana and black plastic, respectively, in plants exposed to the highest doses of FTE-12 and leaf fertilization (Figure 2).

These fruit diameter values are similar to those found by Ventura et al. (2009) in the state of Espírito Santo and higher than those reported by Silva et al. (2010) in Paraíba State.

FTE-12 doses did not affect the contents of SS (Figure 3A), whereas the levels of leaf fertilization affected only the SS of pineapples grown on bagana, as expressed by a linear positive regression 
(Figure 3B). In general, the SS contents obtained in the experiment with black plastic were on average $6.12 \%$ higher than those found in the experiment with bagana. The SS contents measured in this study ( 15.17 to $16.35 \%$ ) were similar to those reported by Ventura et al. (2009). ). Calderón et al. (2010) found values ranging from 11 to $15^{\circ} \mathrm{Brix}$ for soluble solids in the middle third of the pineapple Gold.

With respect to TA the only effect observed was that of foliar fertilization of micronutrients in the experiment with black plastic, with a decreasing linear response, which ranged from 0.88 to $0.80 \%$ for the lowest to the highest doses studied (Figure 4B).

The percentage of TA observed in this study is consistent with the average values found by Ventura et al. (2009). These authors observed a value of $0.8 \%$ for the TA of 'Vitória' pineapples grown in Espírito Santo, fertilized according to the general recommendations applied to 'Pérola' and 'Smooth Cayenne' pineapples. The TA of pineapple fruits may differ between cultivars. For 'Smooth Cayenne' pineapples, grown under different sources of $\mathrm{Zn}$ and B, Maeda et al. (2011) found values of TA ranging from 0.82 to $0.94 \%$. These values are above the average $(0.7 \%)$ found by Ventura et al. (2009) for 'Vitória' pineapples. Lower TA values are usually observed in 'Pérola' pineapples as those reported by Calderón a et al. (2010).

TABLE 1 - Summary of the analysis of variance for weight, diameter, soluble solids (SS) and titratable acidity (TA) of 'Vitória' pineapples in response to micronutrient fertilization at planting (soil) (FTE-12) and on the leaves (LF), of plants grown on bagana and black plastic soil covers, Marco, CE, Brazil, 2010.

\begin{tabular}{|c|c|c|c|c|c|c|c|c|}
\hline \multirow{3}{*}{$\begin{array}{c}\text { Sources of } \\
\text { Variation }\end{array}$} & \multicolumn{8}{|c|}{ Mean Square } \\
\hline & \multicolumn{4}{|c|}{ Bagana } & \multicolumn{4}{|c|}{ Black plastic } \\
\hline & Weight & Diameter & SS & $\mathrm{TA}$ & Weight & Diameter & SS & TA \\
\hline FTE-12 (A) & $0,49 * *$ & $10,09 * *$ & $4,36^{\mathrm{ns}}$ & $0,004^{\mathrm{ns}}$ & $0,77 * *$ & $20,18 * *$ & $4,19^{\text {ns }}$ & $0,014^{\text {ns }}$ \\
\hline Residue (A) & 0,005 & 0,0732 & 2,1734 & 0,0123 & 0,002 & 0,0435 & 3,60 & 0,0119 \\
\hline $\mathrm{LF}(\mathrm{B})$ & $0,59 * *$ & $13,23 * *$ & $12,05^{*}$ & $0,010^{\mathrm{ns}}$ & $0,53^{* *}$ & $15,47 * *$ & $6,39^{\text {ns }}$ & $0,029^{*}$ \\
\hline Int. $(\mathrm{A} \times \mathrm{B})$ & $0,01 * *$ & $0,4354 * *$ & $1,17^{\mathrm{ns}}$ & $0,0002^{\mathrm{ns}}$ & $0,04 * *$ & $0,35 * *$ & $0,30^{\text {ns }}$ & $0,0008^{\mathrm{ns}}$ \\
\hline Residue (B) & 0,008 & 0,0980 & 3,0021 & 0,0124 & 0,0047 & 0,0998 & 3,2381 & 0,0084 \\
\hline CV\% (A) & 9,13 & 2,49 & 9,71 & 13,89 & 6,88 & 2,02 & 11,78 & 12,89 \\
\hline CV\% (B) & 11,10 & 2,88 & 11,41 & 13,96 & 9,34 & 3,07 & 11,17 & 10,81 \\
\hline
\end{tabular}

${ }^{* *},{ }^{*}$ and ${ }^{\mathrm{ns}}$ - significant at $1 \%$ and $5 \%$ of probability and not significant by $\mathrm{F}$ test, respectively. CV - coefficient of variation
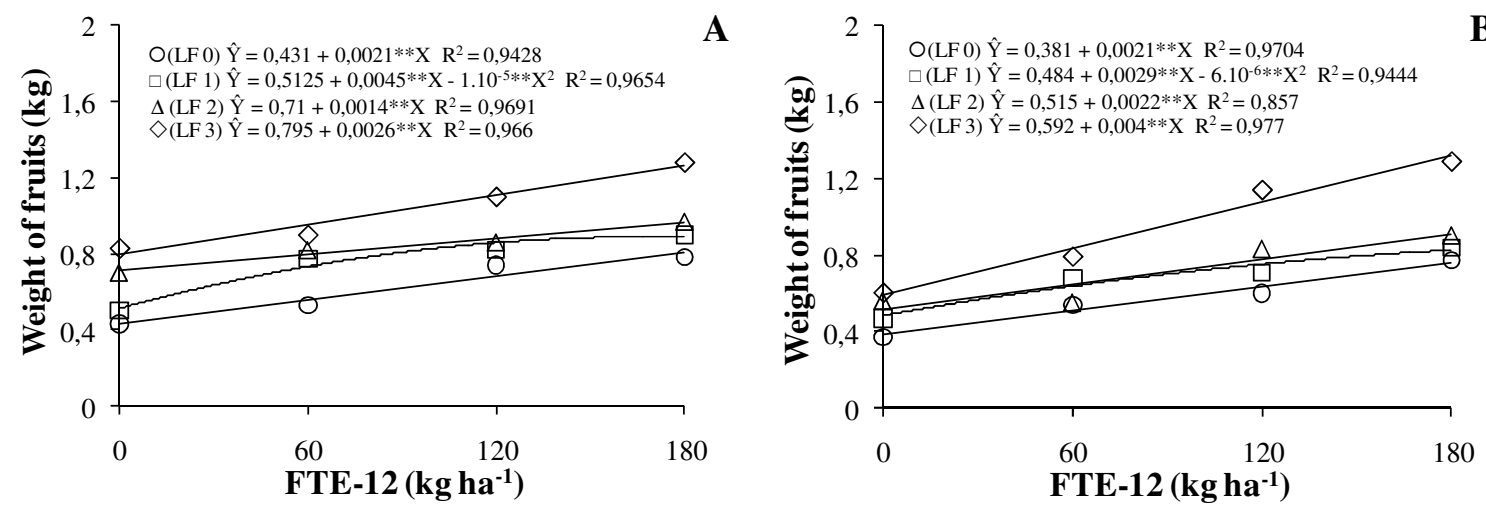

FIGURE 1 - Average weight of 'Vitória' pineapples in response to micronutrients fertilization as doses of FTE-12 and levels of leaf fertilization (LF), under two types of soil covers: bagana (A) and black plastic (B), Marco, CE, Brazil, 2010. ${ }^{* *} \mathrm{p}<0.01$ and ${ }^{*} \mathrm{p}<0.05$ 

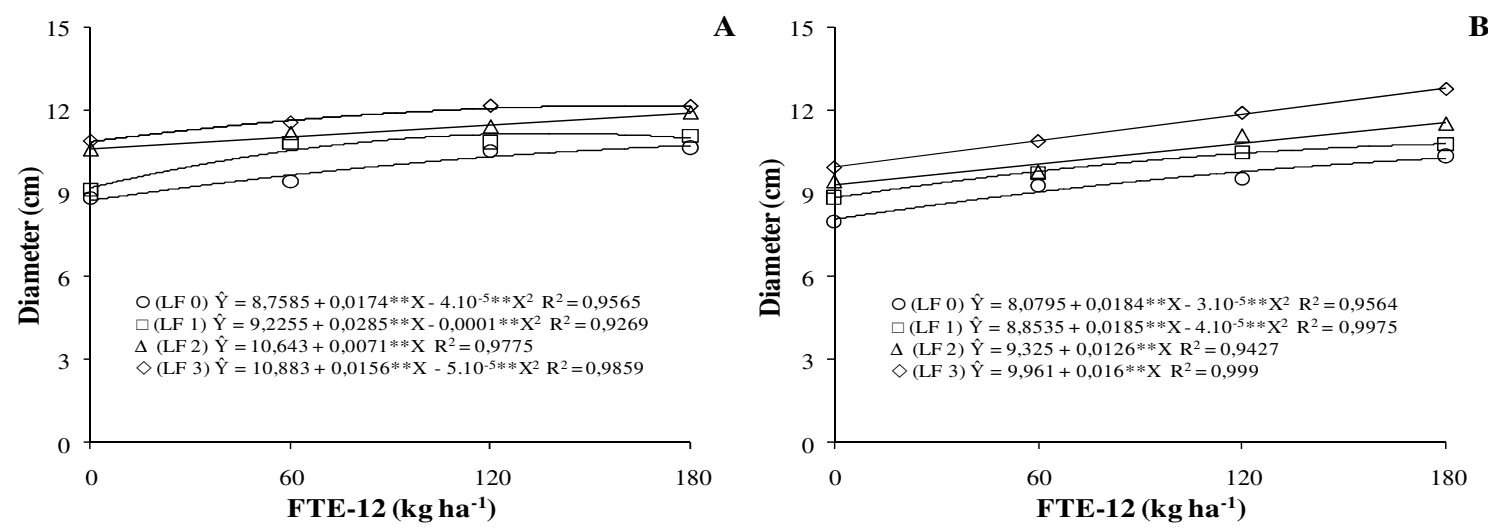

FIGURE 2 - Diameter of 'Vitória' pineapples in response to micronutrients fertilization as doses of FTE12 and levels of leaf fertilization (LF), under two types of soil covers: bagana (A) and black plastic (B), Marco, CE, Brazil, 2010. ${ }^{* *} \mathrm{p}<0.01$ and ${ }^{*} \mathrm{p}<0.05$
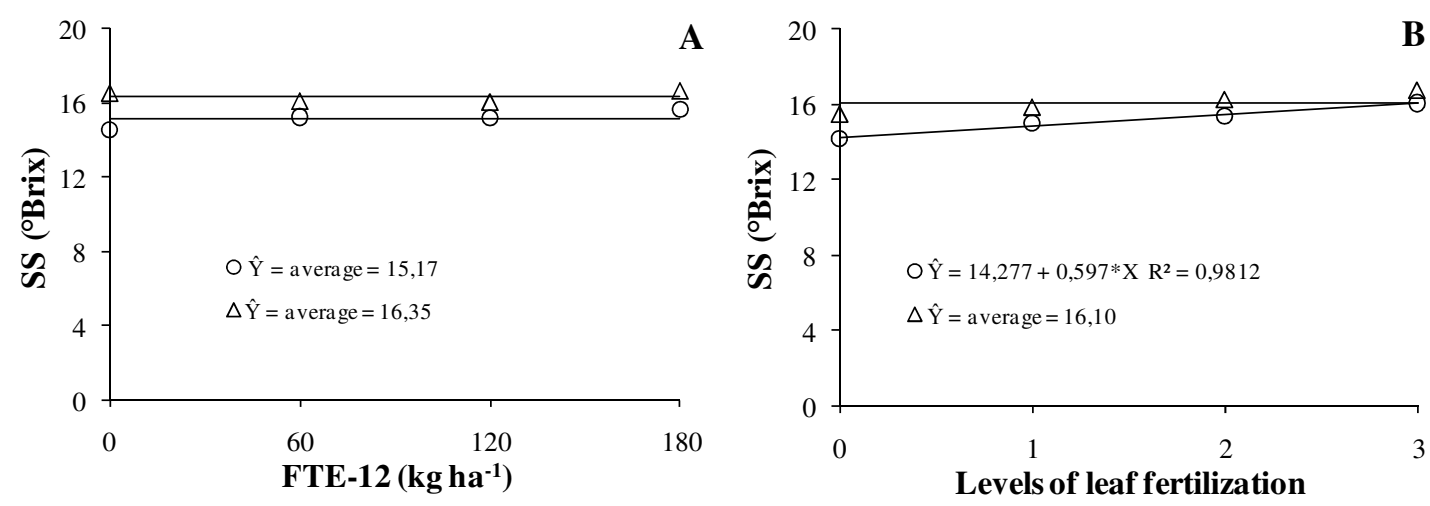

FIGURE 3 - Levels of soluble solids (SS) in the pulp of 'Vitória' pineapples in response to micronutrients fertilization as doses of FTE-12 (A) and levels of leaf fertilization (B), under two types of soil covers: (O) bagana and $(\Delta)$ black plastic, Marco, CE, Brazil, 2010. ${ }^{* *} \mathrm{p}<0.01$ and ${ }^{*} \mathrm{p}<0.05$
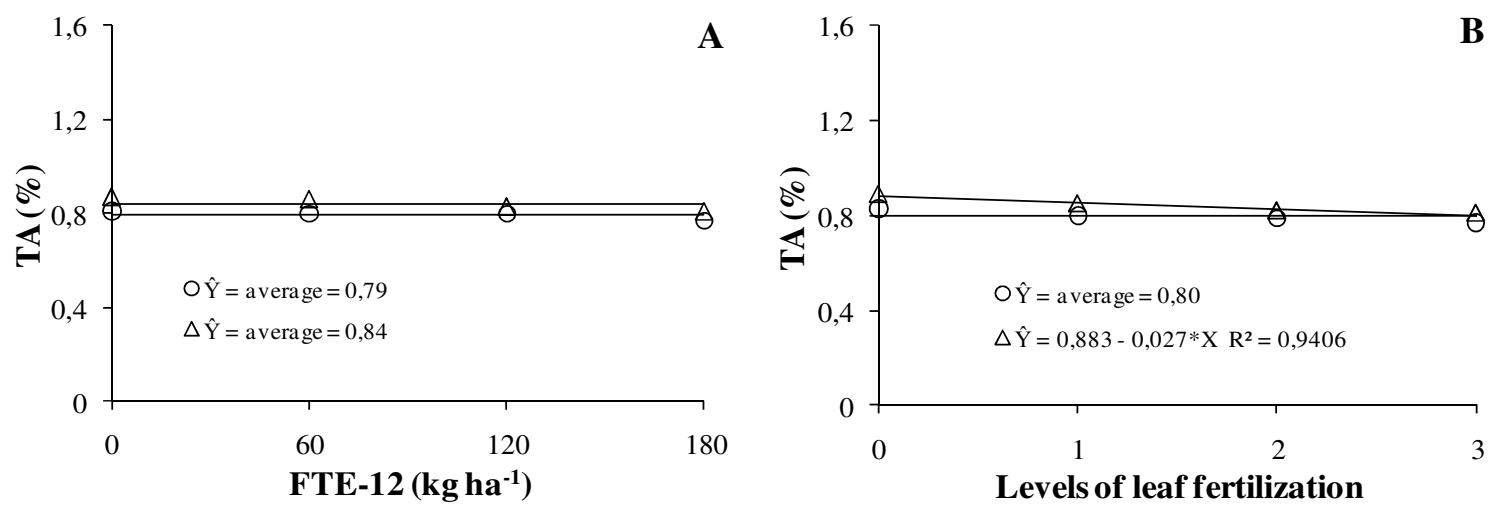

FIGURE 4 - Titratable acidity (TA) in the pulp of 'Vitória' pineapples in response to micronutrient fertilization as doses of FTE-12 (A) and levels of foliar fertilization (B), under two types of soil covers: $(O)$ bagana and $(\Delta)$ black plastic, Marco, CE, Brazil, 2010. ${ }^{* *} \mathrm{p}<0.01$ and ${ }^{*} \mathrm{p}<0.05$. 


\section{CONCLUSION}

1. Under the environmental conditions of the irrigation perimeter of Marco, Ceará State, Brazil, characterized by sandy poor soils, the fertilization with micronutrients both as soil dressing at planting and as foliar application during the vegetative growth of 'Vitória' pineapple plants was essential to increase fruit weight and diameter under the two conditions of soil cover studied: with bagana and black plastic.

2. The same micronutrient supplies had little impact on fruit pulp characteristics. There was no effect for FTE-12 soil dressings, whereas foliar fertilization allowed slight increases in the levels of soluble solids in the experiment with bagana soil cover and slight reduction in titratable acidity in the experiment with black plastic mulch.

\section{REFERENCES}

BRASIL. Ministério da Saúde. Agência Nacional de Vigilância Sanitária. Métodos físico-químicos para análise de alimentos. 4.ed. Brasília: Ministério da Saúde, 2005. 1018p.

CALDERÓN, M. M.; GRAÜ, M. A. R.; BELLOSO, O. M. Mechanical and chemical properties of Gold cultivar pineapple flesh (Ananas comosus). European food Research and Technology, Heidelberg, n. 230, v. 4, p. 675-686, 2010.

CENTRO DE QUALIDADE DE HORTICULTURA-CQH;COMPANHIA DE ENTREPOSTOS E ARMAZÉNS GERAIS DE SÃO PAULO-CEAGESP. Programa brasileiro para a modernização da horticultura: normas de classificação do abacaxi. São Paulo: Ceagesp, 2003. (Documentos, 24).

CHITARRA, M. I. F.; CHITARRA, A. B. Pós-colheita de frutas e hortaliças: fisiologia e manuseio. 2.ed. Lavras: UFLA, 2005. 786 p.

COELHO, R. I.; LOPES, J. C.; CARVALHO, A. J. C.; AMARAL, J. A. T.; MATTA, F. P. Estado nutricional e características de crescimento do abacaxizeiro 'Jupi' cultivado em Latossolo Amarelo distrófico em função da adubação com NPK. Ciências e Agrotecnologia, Lavras, v. 31, n. 6, p. 1696-1701, 2007.
CRUZ, T. M. L.; TEIXEIRA, A. S.; CANAFISTULA, F. G. F.; SANTOS, C. S.; OLIVEIRA, A. D.; DAHER, S. Avaliação de sensor capacitivo para o monitoramento do teor de água do solo. Engenharia Agrícola, Jaboticabal, v. 30, n. 1, p. 33-45, 2010.

MAEDA, A. S.; BUZETTI, S.; BOLIANI, A.C.; BENETT, C. G. S.; TEIXEIRA FILHO, M.C.M.; ANDREOTTI, M. Foliar fertilization on pineapple quality and yield. Pesquisa Agropecuária Tropical, Goiânia, v. 41, n. 2, p. 248-253, 2011.

RAMOS, M. J. M.; MONNERAT, P. H.; PINHO, L. G. R.; CARVALHO, A. J. C. Qualidade sensorial dos frutos do abacaxizeiro Imperial cultivado em deficiência de macronutrientes e de boro. Revista Brasileira de Fruticultura, Jaboticabal, v. 32, n. 3, p. 692-699, 2010.

SIEBENEICHLER, S. C.; MONNERAT, P. H.; CARVALHO, A. J. C.; SILVA, J. A. Boro em abacaxizeiro Pérola no norte fluminense - Teores, distribuição e características do fruto. Revista Brasileira de Fruticultura, Jaboticabal, v. 30, n. 3, p. 787-793, 2008.

SILVA, V. B.; SILVA, A. L. P.; SILVA, A. P.; SOUZA, A. P.; SANTOS, D.; LIMA, L. P. Crescimento e nutrição mineral de abacaxizeiro Vitória, em função da adubação nitrogenada. In: REUNIÃO BRASILEIRA DE FERTILIDADE DO SOLO E NUTRIÇÃO DE PLANTAS. 24., 2010. Anais... p. 256.

VENTURA, J. A.; COSTA, H.; CABRAL, J. R. S.; MATOS, A. P. Vitória: New Pineapple cultivar resistent to fusariosis. Acta Horticulturae, The Hague, v. 822, p. 51- 56, 2009. 